\title{
The Resurrected Body, Will It Be of Flesh or Spiritual?
}

\author{
Theological Discussions from the Time of the Apostle Paul up to the Sixth \\ Century $A D$
}

\author{
Antonia S. Kakavelaki \\ University of Athens, Athens, Greece \\ pahomios@yahoo.gr
}

\section{Summary}

The resurrection of the dead according to Origen and Philoponus is spiritual and not of the flesh. Their opinion, contrary to the official Christian view, was influenced by the neo-Platonic doctrine of "the subtle body of the soul" and based upon Aristotelian logic. Origen's argumentation was formed as a personal interpretation of the passage of the Apostle Paul (1 Cor. 15:39-47) where Paul mentions that the risen body will be spiritual. Philoponus argumentation, on the other hand, was mostly based upon the Aristotelian logic and he thus directed his polemic against the irrationality of the arguments of Cyril of Alexandria and of Gregory of Nyssa.

\section{Keywords}

bodily resurrection - anthropology - Origenism - Gregory of Nyssa - Cyril of Alexandria - John Philoponus

\section{$1 \quad$ Introduction}

In this article we are attempting to give a comparative account of the theological thought mainly of Origen and John Philoponus upon the subject of the resurrection of the dead. In the long history of the Eastern Church this subject matter received different interpretations from the time of the Apostle Paul up to the sixth century (which will be the chronological limit of our present study). We are aiming to show first of all, the difference of approach the 
Pre-Origenic theologians had from Origen, mainly the Apologists, for they conceived the resurrection as resurrection of the flesh, while he insisted in a non corporeal, spiritual resurrection claiming that that was Paul's opinion upon this question. We then proceed to Methodius of Olympus, and Gregory of Nyssa, who continued to support the aforementioned conception and interpreted it each one in their own way, and we mention very briefly Evagrius Ponticus, who seems to be influenced by Origen's thought. Finally we conclude with the work of John Philoponus, who used the same philosophical argument with Origen in order to support a spiritual and not a fleshly resurrection. Our study focuses upon the neo-Platonic and Aristotelian influences on Origen's and Philoponus' thought.

\subsection{Brief Pre-history from the Apostle Paul to Pre-Origenic Theologians}

The notion of the "spiritual" ( $\pi \nu \varepsilon v \mu \alpha \tau i x o$ ) $)$ body appears in the New Testament in the first Epistle of Paul, addressed to the Corinthians. There Paul refers to this type of body while examining the issue of the resurrection of the dead. The resurrection of the dead was in fact one of the questions that seem to have perplexed Timothy, whom Paul had left in Corinth during his second peregrination, in order to organize and help the Corinthian Church. The Apostle Paul mentions "But some man will say: How do the dead rise again? With what manner of body shall they come? ${ }^{1}$ In other words, in this passage Paul raises the question: "What shall the composition of the dead bodies be when the resurrection of the dead takes place?"

This was actually one of the issues that led Paul to write his first Epistle addressed to the Corinthians. In ch. 15, 35-49 Paul talks precisely about the "way of being" of the resurrected bodies. In contrast to the earthly bodies people bear during their life, which are subject to corruption, the future bodies, he says, will be heavenly and incorruptible. ${ }^{2}$ The earthly body is called by Paul "psychic body," while the heavenly body is called "spiritual" ( $\pi \nu \varepsilon v \mu \alpha \tau i x o ́ v) .{ }^{3} \mathrm{He}$ thus distinguishes the soul from the spirit and, in order to further clarify this question, he adds that the psychic body is the one that is created first, and the formation of the spiritual body follows. ${ }^{4}$

As it seems, this reference of the Apostle Paul was a cause of puzzlement already to the early Christian theologians, who tried to clarify this question, each one in his own way. Certainly, this question contained the pre-supposition of a body different of the material one, that is of a spiritual body, and that correlated the thought of the Christians with the wide-spread doctrines of the

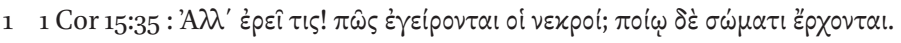

2 1 Cor 15:39-42.

31 Cor. 15:44-45.

4 1 Cor. 15:46-47.
} 
mystical beliefs of that time, and particularly with the neo-Platonic doctrines which were related to the notion of the spiritual body.

The primary issue that occupied the Christian thought was that of the resurrection of the body of Jesus Christ. How could the mystery of his resurrection be interpreted? With which body did that take place, the natural/fleshly one, or, as Paul mentions, one of a different type, a spiritual one. And if the latter is the case, what would its particular composition be? In other words in what would it differ from the natural/fleshly body? In addition to all these, how could the question of the resurrection of the dead at the time of the Second Coming be interpreted.

In the Orthodox East, various opinions concerning the resurrection of both body and soul were formulated from a very early time, in order to reject the ideas, initially of the Gnostics, (which were basically anti-cosmic dualists and thus could not accept the resurrection of the flesh), and later of Origen and his followers, who believed in the resurrection of a spiritual subtle body - influenced by their contemporary medio-Platonic doctrines. But let us examine these in more detail.

In a text which had in the past been attributed to Clement of Rome, i.e., the second sermon or homily in Corinth (most probably around the end of the first century AD), ${ }^{5}$ we witness for the first time a new conception of the resurrection, namely the resurrection of the flesh. The author of this text mentions precisely the following:

And should not any one of you say that the flesh itself is not being judged or resurrected. For you should know inside what you were saved, inside what you opened your eyes if not by being inside this flesh. We must thus guard the flesh as temple of God. For in the same way as you were called inside the flesh, you will come < again $>$ to it. < The > one Christ, the Lord, he who saved us, which is the first spirit, became flesh, and he called us in this way. So we too, shall receive the recompense. ${ }^{6}$

5 O.G. Stanton, "2 Clement vir and the origin of the document," Classica et Mediaevalia, Kopenhagen, 28 (1970), pp. 314-320 claimed that the text should be dated around 180 AD. K. P. Donfried, The Setting of Second Clement in Early Christianity, Leiden, 1974, pp. 1-48 dates it around 98 to $100 \mathrm{AD}$. The same opinion is also held by B. Schmisek, Resurrection of the Flesh or Resurrection from the Dead, Implications for Theology, Collegeville, Minnesote, 2013, p. 7.

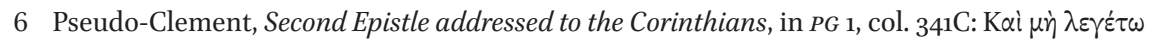

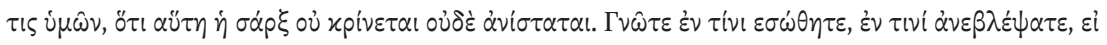

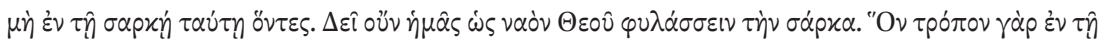

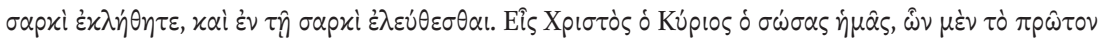

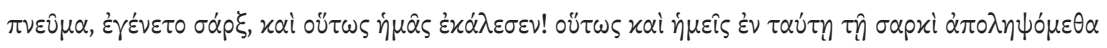

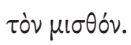


In the work of the Apologists (second half of the second century) also, we find the doctrine of the resurrection of the dead $n$ flesh.

Justin the Martyr (100-165 AD) in his First Apology claimed that: "Human bodies, even when they are destroyed, and are decomposed like germs into the earth, it is not impossible, when the time comes and God commands, to resurrect and to be clothed in incorruptibility." Tatian (ca. 120-180 AD) too, in his Address to the Greeks, while referring to the resurrection says the following: "Therefore the soul of man is composed by many parts and is not of one part. For it is composite, as it become visible by means of the body. For it would never appear without the body, nor does the flesh rise without soul."8

Irenaeus (130-202 AD), in the fifth book of his work Against Heresies, refers at length on the question of the resurrection of the flesh, because his Gnostic opponents seem to have used the fragment of the Apostle Paul $15.44^{9}$ to argue for a spiritual resurrection and to reject the doctrine of fleshly resurrection. He thus mentions: "If the flesh was not to be saved, the Word of God would have never been flesh. And if the blood of the just was not greatly sought after, the Lord would never have had blood."10

Athenagoras (ca. 133-190 AD) also argued in favour of the resurrection of the flesh simultaneously with that of the soul. In his treatise On the Resurrection he claims that:

It is absolutely necessary that there be a resurrection of the bodies that have died or have been entirely dissolved, and the same human beings must be composed again .... But it is impossible the same human beings to regain their composition unless the same bodies are given back to the same souls. ${ }^{11}$

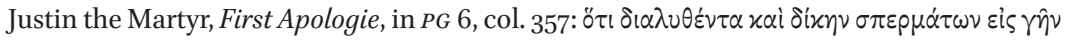

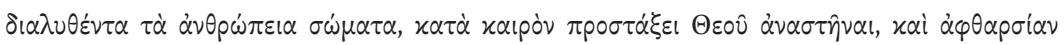

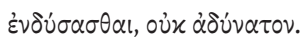

8 Tatian, Adress to the Greeks, in PG 6, col. 837

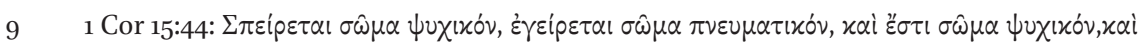
$\varepsilon ้ \sigma \tau \iota \sigma \hat{\omega} \mu \alpha \pi \nu \varepsilon v \mu \alpha \tau \iota x o ́ v$. Irenaeus, Against Heresies, in $P G$ 7, col. 1161: "Si enim non haberet caro salvari, nequaquam Verbum Dei caro factum esset. Et si non haberet sanguis justorum inquiri, nequaquam sanguinen habuisset Dominus."

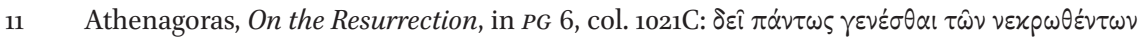

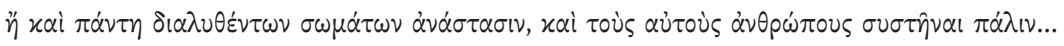

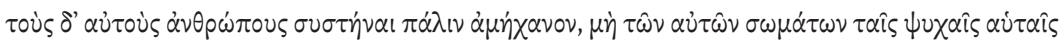
$\dot{\alpha} \pi 0 \delta 0 \theta \varepsilon \dot{\varepsilon} \tau \omega \nu$. 
Thus, as we have showed, the Apologists interpreted the doctrine of the resurrection as one that includes the flesh, so as to reject any perception of it as exclusively of an immaterial state of the soul.

\section{The Interpretation of Origen}

Origen (185-253/4) brought again to the foreground the Apostle Paul's position about the "spiritual body" rejecting the teaching of his theologian predecessors regarding the resurrection of the flesh.

Origen, attempting to further clarify the mystery of the resurrection as presented by Paul, perceived on the one hand that Paul was talking about a bodily resurrection of the dead, but at the same time concluded that according to Paul, these bodies could not be composed by flesh and blood, for Paul mentioned explicitly that: "the flesh and the blood cannot inherit the kingdom of God neither can the corruption inherit the incorruption". ${ }^{2}$ Thus, Origen based upon Paul's text, considered as a given that the resurrected body undergoes a radical transformation, because if one conceives the resurrected body as identical with the earthly body, it is as if he considers that Apostle Paul in his Epistle contradicts himself.

It is upon this question that he directs his thought when in his treatise $O n$ First Principles 2.10.3 he says:

Certainly, if they believe the Apostle who says that the body, when it has risen in a state of glory and force and incorruption, has then being rendered spiritual, $<$ then $>$ it seems illogical and contrary to what $<$ Paul $>$ means if one says that $<$ in this state too $><$ the resurrected body $>$ interweaves with the passions of the flesh and of the blood. ${ }^{13}$

In his Commentary of the Psalms, in a passage that is preserved in the text of Methodius of Olympus entitled Aglaophon or on the Resurrection, he presents in length his opinion upon the flesh contrasting it with the body which will rise. This passage is considered by all recent scholars as being the more indica-

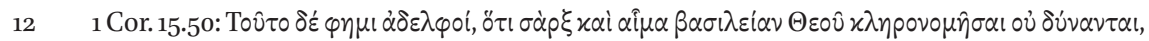

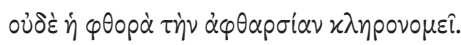

13 Origen, On First Principles, ed. H. Crouzel, M. Simonetti (sC, 252), Paris, 1978, p. 380, II.10.3: "Quod utique si credunt apostolo quia corpus in Gloria et in uirtute et in incorruptibilitate resurgens, spiritale iam effectum sit, absurdum uidetur et contra apostolic sensum dicere, id rursum carnis et sanguinis passionibus implicari."
} 
tive passage of Origen's thoughts upon this matter. In this he discusses the following:

... because each body is sustained by grace of a nature which assimilates in itself some things found outside it for nutrition and excrete other things in place of the ones it inserted, like these of the plants and of the animals, the material subject is never the same. For this reason, of course, the body was not erroneously named a river, for, in accuracy, the prior substrate inside our body might not be the same even for two days, although in a way, Paul or Peter is always the same (not regarding the soul, the essence of which neither flows, according to us, nor does it ever have anything in addition) even if the nature of the body is fluid, for the eidos that characterizes the body is the same, as the traces too that represent the fleshly quality of Peter and Paul remain the same, by which quality from their childhood there remain scars on the bodies and some other properties like freckles and apart from these any other thing which is alike $<$ to them $>$. $^{14}$

And he continues mentioning that:

As the eidos exists from the time that one is an infant until he becomes old, even if the characteristics $<$ that one receives $>$ seem to have a big difference, so one must understand the eidos that we treat here: that it will be the same in the future even if its change will be much for the better. Because it is necessary for the soul, as it found in corporeal places, to use bodies adequate for $<$ these $>$ places. For in order to live inside the sea we should have become aquatic and we should necessary have bronchia and the other characteristics of the fish, so too those that shall inherit the kingdom of the Heavens and must be in different places should use

14 Methodius of Olympus, Aglaophon or on the Resurrection, ed. N. Bonwetsch (GCS, 27),

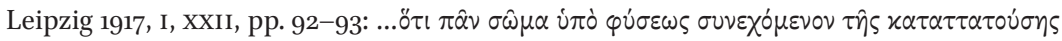

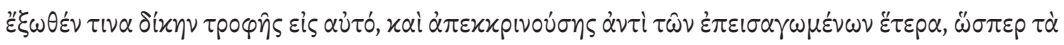

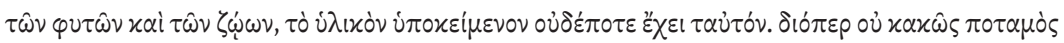

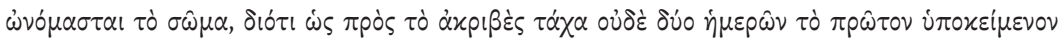

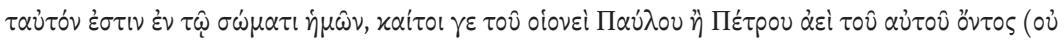

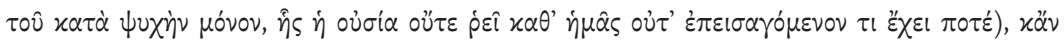

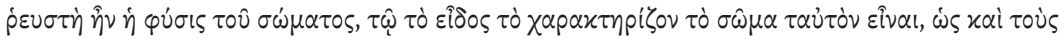

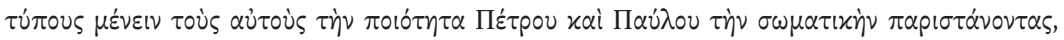

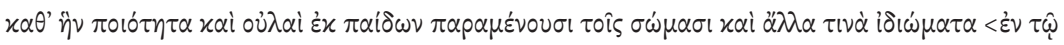

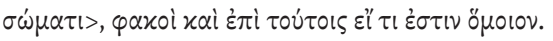


'spititual bodies', of course not that the previous form is annihilated, even if it turns to the more glorious, exactly as the eidos of Jesus and of Moses and Elias was, $<$ that is $>$ it was not different than what it was previously in the metamorphosis. ${ }^{15}$

And in what follows Methodius concludes:

for it will be a body that which will be around the saint, held tightly by that which once gave eidos to the flesh, but it will no longer be flesh. But that which once was characterized inside the flesh will be characterized in the spiritual body. ${ }^{16}$

In these passages we find the term eidos which usually is being translated by the modern scholars as form. But the term form does not actually explain the specific meaning eidos in philosophical language. For if it meant 'form,' what would Origen mean by saying that the eidos remains the same although the body - the primary substrate changes throughout the life? In fact the term $e i-$ dos is found in the Aristotelian de Anima where it has the specific meaning of $\varepsilon^{\prime} \nu \tau \varepsilon \lambda \varepsilon^{\prime} \chi \varepsilon \alpha_{\alpha}{ }^{17}$ and consequently is a synonyme of the soul. ${ }^{18}$

And towards the end of this text, in a passage which according to Crouzel is most probably drawn from Origen's lost text on the Resurrection, ${ }^{19}$ Methodius claims that the soul, after death, is dressed by a bodily envelope, which this time he calls, according to the medio-neo-Platonic tradition, vehicle of the

15 Methodius of Olympus, Aglaophon or on the Resurrection, I, XXII, pp. 93-95:

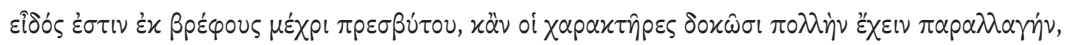

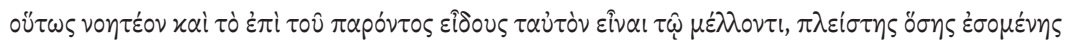

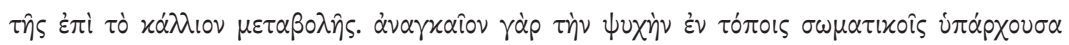

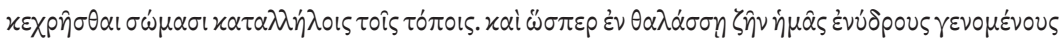

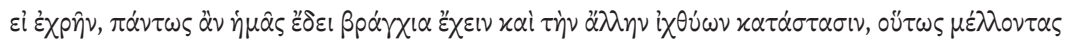

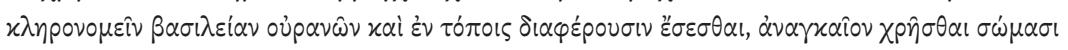

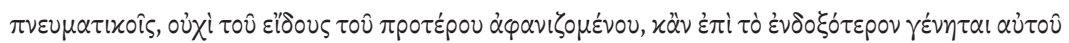

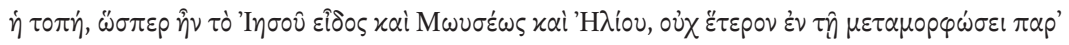
oิ ทेข.

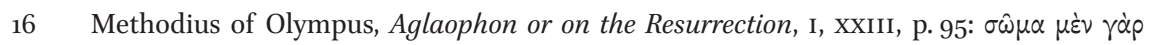

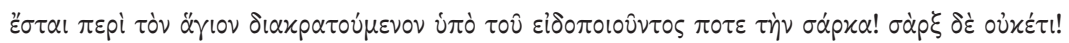

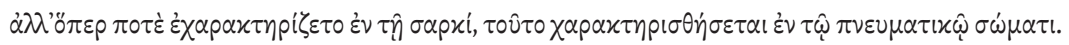

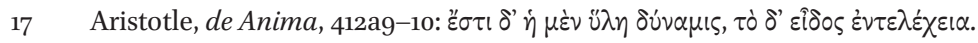

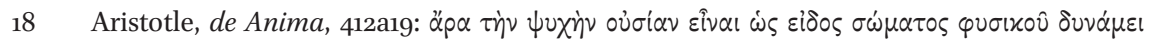

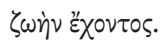

19 H. Crouzel, "Le thème platonicien du 'véhicule de lâme' chez Origène," DIDASKALIA, 7 (1977), pp. 225-238 (see p. 226). 
soul. This vehicle, as he had said in the previous passage too, is alike in shape with that which the soul had when it bore flesh. ${ }^{20}$

Origen was most certainly influenced by contemporary philosophical thought which consisted in a syncretism of Eastern mystical religious doctrines, (namely the Hermetic Corpus and the Chaldean Oracles) and philosophical doctrines that were about to form a whole theory of a spiritual body, and that were to become one of the preponderant neo-Platonic doctrines.

Origen talks about the "pneuma" as the vehicle of the soul. So let us take a look how these two terms "spirit" and "vehicle of the soul" were connected at his time in order to better understand Origen's thought.

The notion of the "pneuma" was first connected to the notion of "vehicle" in a text of Pseudo-Plutarch (dated by Diels around the 2nd century). ${ }^{21}$ In this text the author refers to eschatological questions. It is in fact an interpretation of the eleventh rhapsody of the Odyssey. There the author refers to the spiritual body as being its vehicle, and by which an intermediate form of "bodily life," that is of a "spiritual life" is illustrated. The passage is the following:

Plato and Aristotle considered that the soul is incorporeal, but it always constitutes the soul of a body, and needs it as a vehicle. For that reason even when it is released from the body, it carries along with it the pneumatic body, often preserving the form it had when it was inside the body as imprint of it. ${ }^{22}$

These two terms are also found to be connected in the Hermetic corpus (2nd-

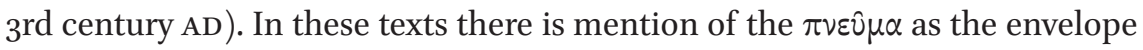
of the soul upon which it is carried. ${ }^{23}$

The Chaldean Oracles too (2nd century) contain a metaphysical teaching related to the pneuma and they are considered as the most influential texts for the later neo-Platonic conception of this notion. In fragment 120 there is

\footnotetext{
20 Methodius of Olympus, Aglaophon or on the Resurrection, III, XVII, p. 413.

21 H. Diels, Doxographi Graeci, Berlin, 1879, p. 99.

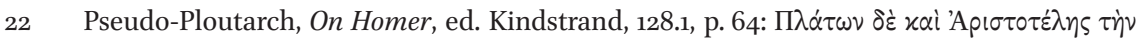

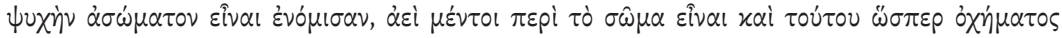

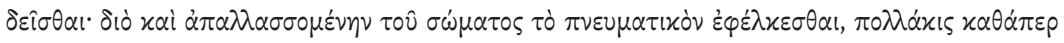

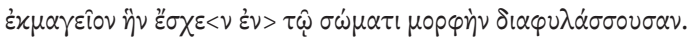

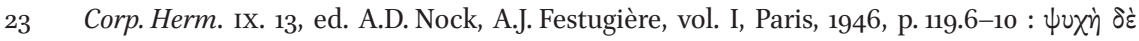

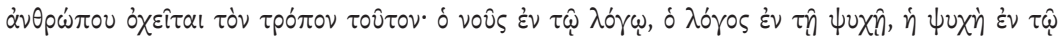

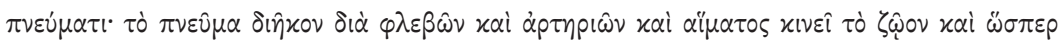

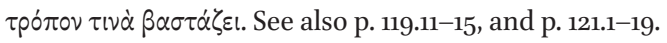


mentioned a "subtle vehicle of the soul,"24 and the doctrine that the soul, during its descent collects particles from the planets and the elements. Finally Noumenius too (about the 2nd century AD) was influenced by the Chalean Oracles and claimed that the soul, during its descent, is dressed from each planet by an ethereal envelope, and that these envelopes prepare gradually its union with the terrestrial body. ${ }^{25}$

Although in all these texts there is mention of the "pneuma" of the soul as its ethereal luminous and subtle body, what is interesting is that a comprehensive theory about the "pneumatic" body was formed later on, by the neo-Platonist philosopher Porphyrius (232-304/10). For the neo-Platonic philosophers this doctrine served as a compromise between Plato's conception of the soul as separable from its earthly body, and Aristotle's belief that the soul is the first actuality of a natural body that is potentially alive. ${ }^{26}$ Plotinus, the father of neo-Platonism, alludes to this doctrine although he does not develop it extensively in his work. In the Enn III.6.5.22-29, Plotinus presents the "pneuma" as the vehicle of the passive part of the soul. In the Enn. IV.3.15, while referring to the descent of the souls, he says that when the souls leave the intelligible realm, before their final descent to the material realm, they first go to heaven where they put on a body, and then, they move on towards the more terrestrial bodies. Finally, in the Enn. IV.3.24 Plotinus hints at the "pneuma" as the subject of the souls which are punished in Hades. In other words, it seems most probable that Origen was influenced by the sources we mentioned above and by Plotinus.

The way Origen conceives the matter is the same as that of most philosophers: he distinguishes a substratum non-form essence and a quality that procures form and may change. The bodily essence changes and can pass from one form to another. ${ }^{27}$

According to Origen only the Holy Trinity is absolutely incorporeal. ${ }^{28} \mathrm{Al}-$ though the souls of rational creations are incorporeal, there are always joined

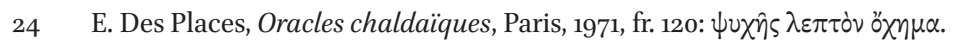

25 Macrobius, In Somnius Scipionis, ed. M.A. Marchetti, Paris 2003, p. 69, I.12-13.

26 E.R. Dodds, Proclus - The Elements of Theology, Oxford, 1963, Appendix II, pp. 316-317.

27 Origen, On First Principles, ed. H. Crouzel, M. Simonetti (sc, 268), Paris, 1980, p. 416, IV.4.6: substantia corporalis permutabilis sit et ex omni in omnem deueniat qualitatem.

28 Origen, On First Principles, ed. Crouzel, Simonetti (sC, 252), p. 206, I.6.4: "quomodo tot et tantae substantiae uitam agere ac subsistere sine corporibus possint, cum solius dei, id est patris et filii ac spiritus sancti naturae id proprium sit, ut sine materiali substantia et absque ulla corporeae adiectionis societate intellegatur existere," see also II.2.2, p. 246: "Si uero inpossibile est hoc ullo modo adfirmari, id est quod uiuere praeter corpus possit ulla alia natura praeter patrem et filium et spiritum sanctum..." 
to bodies. Corporality is the condition of their existence, a condition from which the angels and the demons are not exempt. This is thus the perspective through which the resurrection is perceived.

Furthermore, although Origen denies that ether is a fifth element, ${ }^{29}$ in some passages of his work he does speak of a certain state of corporeal matter that has become identical with the ether, of the body of the stars as being ether, and of a region on top of the air that is called ether. For him it is not a question of a body or an element, but of a quality of matter which represents the most subtle state, quasi spiritual, that it can have. For this reason in his work Against Celsus he says: "For it is worth wondering how by the providence of the willing God the mortal quality of the body of Jesus was altered into ethereal and divine quality..."30

Furthermore Origen used the term "luminous" ( $\dot{\alpha} v \gamma o \varepsilon ı \delta \varepsilon \varepsilon$ ), that the neo-Platonic philosophers used in order to define the "pneumatic body," for the body of the ghosts that appear around the tombs and for the angels and the resurrected humans which would resemble the angels. ${ }^{31}$

Origen's opinions received strong criticism by the official Church. They were condemned both by the decree of Justinian (fifth anathema) ${ }^{32}$ and by the fifth Ecumenical Council (Tenth anathema). ${ }^{33}$ In fact this position of non-fleshly resurrection was considered by its opponents as a negation of the resurrection.

3 Origen's Opponent Methodius of Olympus

Methodius of Olympus, (bishop and martyr ca. 311-312) was one of the bestknown opponents of Origen's doctrine. In his work entitled Aglaophon, or on the Resurection, he shows a hostile attitude to Origen's doctrine (and the Origenists in general) related to the "pneumatic" body that the soul will bear at the moment of its resurrection. In the following passage of his work we find a summary of the way he refutes Origen's ideas:

29 Origen, On First Principles, ed. Crouzel, Simonetti (sc, 268), p. 248, III.6.6: "Non enim secundum quosdam Graecorum philosophos praeter hoc corpus, quod ex quattor constat elementis, aliud quantum corpus, quod per omnia aliud sit et diuersum ab hoc nostro corpore."

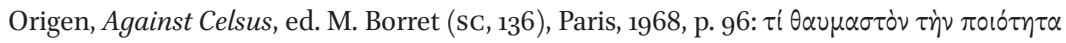

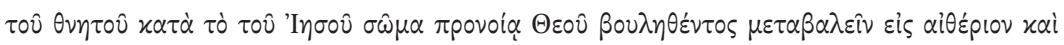
$\theta \varepsilon i \alpha \nu \pi 010 ́ \tau \eta \tau \alpha$

Origen, Commentary on Matthew, ed. E. Klostermann, E. Benz (GCS), Berlin, 1935, p. 671.10.

32 Acta Conciliorum Oecumenicorum, ed. E. Schwartz, Berlin, 1940, vol. 3, p. 213.25-26.

33 Ibid., p. 249.19-22. 
If someone considers that the flesh itself is called terrestrial image, and heavenly image another body, spiritual, different from the flesh, let him recall first of all that Christ, the heavenly man, appeared to bear the same shape of body and of members and image and flesh identical to ours, by which, although he was not a man he became man, in such a way exactly 'because of the relation and union with Adam all its descendants die, and so by their relation and union with Christ all shall be vivified. ${ }^{34}$ For if he bore flesh, not in order to liberate and to resurrect the flesh, for what reason did he bear par excellence flesh, which he would neither save nor rise? But the son of God does nothing superfluous. Consequently he did not assume the form of the slave in vain, but so as to resurrect it and to save it. Because he became truly man and really died, ... so as to appear truly first-born of the dead, transforming the earthly into heavenly and the mortal into immortal. ${ }^{35}$

Thus, according to Methodius, the fact that Jesus appeared bearing flesh while he was a heavenly and immortal being means that he rendered the flesh spiritual and heavenly, thus capable of rising again.

As it seems the discussions about the fleshly or spiritual resurrection had not yet come to an end. Evagrius of Pontus for example, whose work too was condemned by the Fifth Ecumenical Council, maintained the abolition of the bodies after death in a progressive way: first the terrestrial bodies will be transformed into spiritual bodies, and will be similar to the resurrected body of

$34 \quad 1$ Cor 15:22.

35 Methodius of Olympus, Aglaophon or on the Resurrection, ed. N. Bonwetsch (GCS, 27),

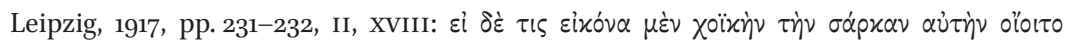

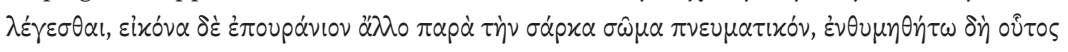

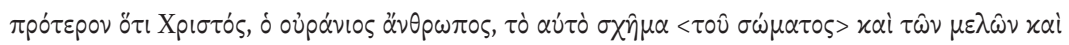

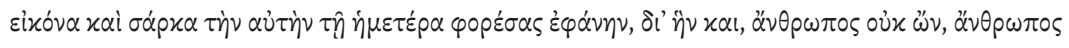

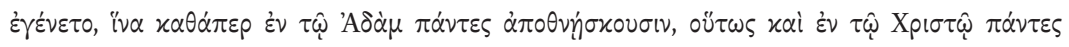

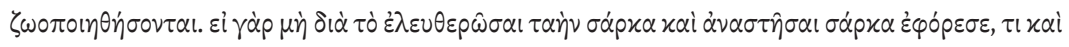

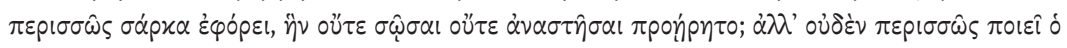

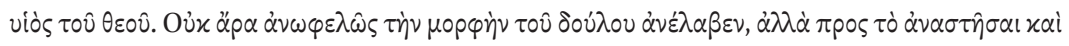

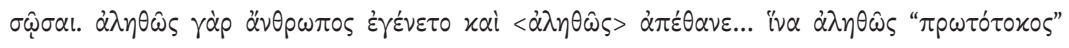

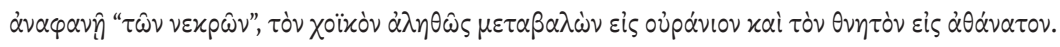


Christ. And finally all the bodies, material or spiritual, will disappear so that the intellects are united with God. ${ }^{36}$

As the opinions about a non corporeal resurrection were still taking place, we see Gregory of Nyssa making a lengthy argumentation for the fleshly resurrection. This argumentation is found in two of his works. The first one is entitled On the Soul and the Resurection, known also as Macrinia, which is actually a dialogue between Gregory and his sister Macrina that deals with the resurrection of the body after death, where the following opinion is expressed by Macrina:

You must understand the soul in the same way, $<$ that is $>$ by the elements that cohere in order to < produce $>$ the body's creation, inside which it came into existence, and after the destruction of these <elements $>$ by the $<$ body's $>$ natural disposition. And even if nature attracts them in a counter manner $<$ than to be attracted to each other $>$, because of the inherent oppositions < they have as to their proper dispositions $>$, it defends each one of them from being mixed with their counter <element $>$, < although the soul $>$ remains $<$ inherent $>$ in each one of them by its cognitive power which attains its fitting <elements $>$ and remains $<$ in life/in existence $>$ until the joining of the <elements $>$ that have been driven apart join again $<$ so as to form $>$ the same $<$ being $>$ in order that the body under destruction regains its $<$ former and proper $>$ elements - that which most certainly is resurrection per se, and is so called. ${ }^{37}$

We thus have Macrina saying that the elements that were formerly joined together, in order to form the human body, although being later on dispersed, will one day join again so as to form anew the destructed body when its resurrection takes place.

The second text of Gregory of Nyssa which presents the same opinion in a more analytic way is the one entitled On the creation of Man. ${ }^{38}$ His argumenta-

36 Evagrius of Pontus, Kephalaia Gnostica, 1.26, and 11.77, see A. Guillamont, Un philosophe au désert: Évagre le Pontique, Paris, 2004, pp. 391f.

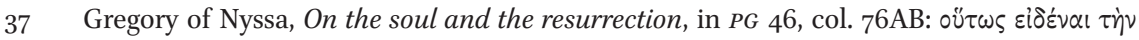

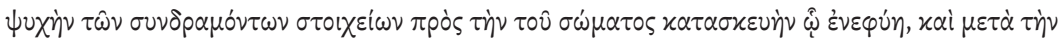

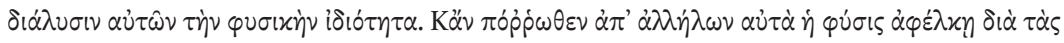

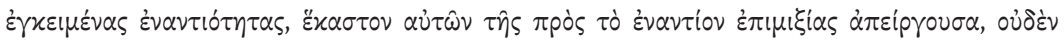

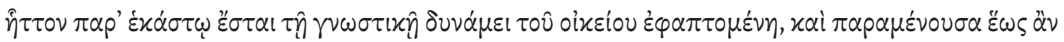

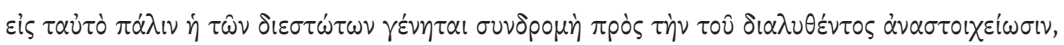

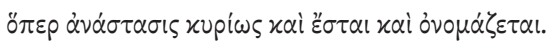

38 Gregory of Nyssa, On the Creation of Man, in PG 44, cols. 123-256. 
tion starts from the twenty-seventh chapter where he mentions that although man's body is dispersed in the element by which it was constituted, ${ }^{39}$ the doctrine that certain people claim is a erroneous belief, namely: "That God cannot by the particular paths, $<$ that is $>$ by the resurrection, restore the particular nature of man." 40

He says that it appears to be difficult, after the dissolution of the elements into the elements of the same species to return each one of them from the common source to its particular $<$ body $>$, and he concludes by stating the doctrine that he adopts, which is the following:

The soul maintains a certain natural relation and affection towards the body with which it cohabited, and because of its union with it, there is a certain secret relation and awareness of its intimate, as if $<$ there are $>$ some signs that the nature has placed, by which the common source remains without union and is distinguished in the particular <elements that constitute it $>.41$

Thus, as the soul attracts again towards itself its familiar and particular $<$ body $>$, tell me, what difficulty would prevent the divine power from joining together of its familiar <elements $>$, which by a certain mysterious natural attraction are transferred towards their familiar $<$ to them elements $>$ ? 42

Because the fact that certain traces of our composite $<$ body $>$ remain even after its dissolution, is shown by the dialogue that takes place in Hades. Even if the bodies are placed into the grave, some corporeal characteristic remains with the souls by which Lazaros too was recognized, and the rich $<$ man $>$ was not ignored. ${ }^{43}$

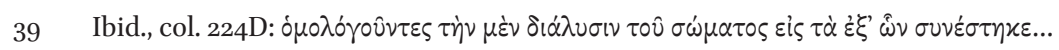

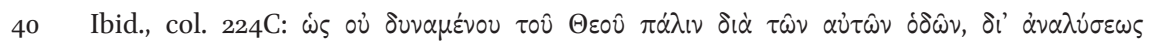

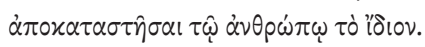

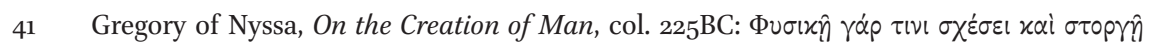

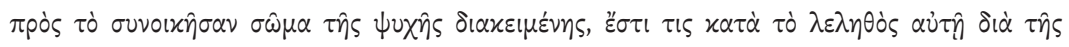

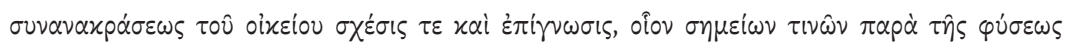

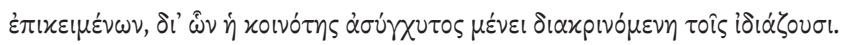

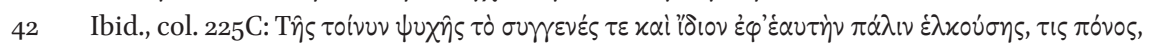

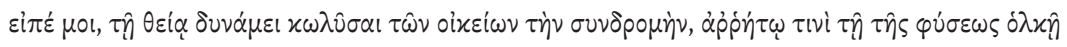

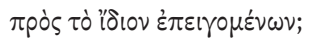

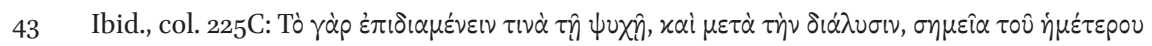

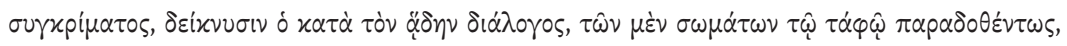

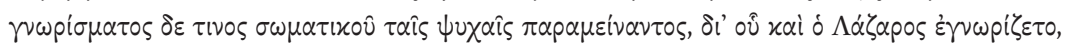

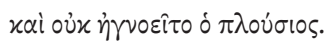


In what follows Gregory says that the eidos of the body itself remains unaffected from any alteration, ${ }^{44}$ and he completes his syllogism by claiming that:

... the eidos necessarily remains on the soul like the mould of a seal and it does not ignore neither those that imprinted the sign by the seal, but by the time of its regeneration $<$ the soul $>$ accepts again towards itself these $<$ elements $>$ that it will adopt to the print of the eidos. It will certainly adopt $<$ the elements $>$ that were imprinted in the beginning into the eidos. ${ }^{45}$

Concluding, for Gregory of Nyssa the soul, after the death of the body retains a print of the eidos of the elements that it had while being in life, and at the time of the resurrection of the body these elements are recomposed so as to form anew its original body. Thus Gregory of Nyssa is trying to form a whole theory in order to refute the opinions about a non-fleshly resurrection, like those expressed by Origen.

\section{The Case of John Philoponus}

The last person whose opinions upon this very subject we shall present here is John Philoponus (490-570 AD), who was a member of the neo-Platonic school of Alexandria and pupil of Ammonius before engaging himself exclusively in Christian theology. In the first periode of his career, when he expressed himself as a neo-Platonic philosopher, he adopted Proclus' and his masters' Syrianus opinion of two kinds of subtle bodies, one that is not eternal, that constitutes the seat of anger and desire, from which the soul is delivered when it purifies itself, and another heavenly body, which is eternally joined to the rational soul,

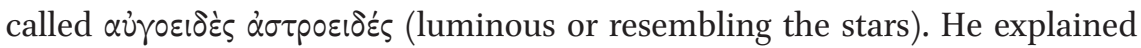
the reason why this second kind of eternal body exists as follows: Because the soul belongs to the earthly beings it is necessary for it as well to have a certain lot over which it rules, through which it may be part of the world. And since it is eternally moving and always acting, it must also have eternally a body to vivify. ${ }^{46}$ In the beginning of the second period of his career, when writing as a Christian philosopher, he criticized theories incompatible with the Christian

\footnotetext{
44 Gregory of Nyssa, On the Creation of Man, p. 225 D

45 Gregory of Nyssa, On the Creation of Man, p. 228 B.

46 Philoponus, Commentary on Aristotle's on the Soul, ed. M. Hayduck (CAG, 15), Berlin, 1897, p. $18.26-31$.
} 
doctrine, and he refuted the existence of the "eternal body"47 because it presupposed the pre-existence of the soul.

Later on, upon the subject of the resurrection, he seems to have held a doctrine similar to Origen's about an unchangeable eidos, and a body that changes constitution, that is created anew by God, and is incorruptible and eternal. But let us examine his thought on the subject of the Resurrection in more detail.

Of Philoponus' work on the resurrection some fragments survive in Syriac in a Cononite ${ }^{48}$ anti-Philoponian florilegium which contains several passages of the lost works of Philoponus, ${ }^{49}$ and a limited reference to his ideas is also found in the late sixth-century Chalcedonian catalogue of heresies by Timothy, presbyter of Constantinople. ${ }^{50}$ Unfortunately, these sources provide us only with a general outline of Philoponus' doctrine which is rather confusing.

Philoponus did not accept the doctrine of material identity between the dead and the resurrected bodies. On this very point he stood precisely against the doctrine expressed by Cyril of Alexandria in the seventh book of his commentary of the first Epistle of Saint Paul to the Corinthians, and of Gregory of Nyssa.

As to the doctrine of Cyril that the resurrected bodies will be what they were but incomparably nobler, incorruptible and immortal, Philoponus' criticism is that if one accepts that the resurrected bodies will be immortal, but at the same time insists that these retain identity of nature with the dead bodies, he destroys the identity of man, for man is a living being who is reasonable and mortal. ${ }^{51}$

According to Philoponus, the resurrected bodies will be different from the previous ones, created by God as better than they, incorruptible and eternal. ${ }^{2}$ Thus he also rejected Gregory's of Nyssa doctrine on the identity of matter between the dead and the resurrected bodies. Let us recall that Gregory had

47 Philoponus, Against Proclus. On the Eternity of the World, ed. H. Rabe, Leipzig, 1899 (repr. Hildesheim, 1984), p. 245.22-26, and pp. 272.27-293.15.

48 The Cononites were Philoponus' former "Tritheite" followers who later on rejected him.

49 A. Van Roey, "Un traité cononite contre la doctrine de Jean Philopon sur la Résurrection," in: ANTIS $P$ PON. Hulde aan Dr. Maurits Geerard hij de voltooiing van de Clavis Patrum Graecorum, vol. 1, Wetteren, 1984, pp. 123-136. PG 86, 1.

$5^{1} \quad$ L. Wickham, "John Philoponus and Gregory of Nyssa's Teaching on Resurrection - A Brief Note," in: Studien zu Gregor von Nyssa und der christlichen Spätantike, Leiden, 199o, pp. 205-210 (see p. 206). B. Lourié, "John Philoponus on the Bodily Resurrection," Scr, 9 (2013), pp. 79-88 (see pp. 82-85). 
argued that the elements that composed the human body will be joined together again in the resurrection. ${ }^{53}$

More precisely, as Timothy mentions, Philoponus defined the resurrection of the dead as the insoluble union of rational souls with an incorruptible body. He also says that the Cononites in the beginning adopted Philoponus' thought, but later on rejected him and his writings and claimed the same doctrine as Gregory of Nyssa, namely that the resurrection of the dead is defined as the second insoluble union of the body with the rational soul. ${ }^{54}$

Moreover according to the doctrine attributed to Philoponus by both Timothy and the Cononite florilegium, he professed that the visible bodies which were created by God according to the mater and the eidos from the non being into being, were made corruptible, and they are destroyed according to both matter and eidos ( $\varepsilon i \delta \circ \varsigma$ ). Basil Lourié sees a problem arising from the claim of the destruction "according to the eidos," since from the criticism that Philoponus addressed to Cyril, one can deduce that it is Cyril who is denying that the resurrected human beings will belong to the same human essence, and not Philoponus. We should also add at this point that the word eidos in Philoponus' Commentary on the Categories is presented as "that which completes the essence of each thing, and when this is destroyed the subject (i $\pi \circ x \varepsilon i \mu \varepsilon v o v$ ) is destroyed as well." ${ }^{55}$ And in the in de anima Philoponus is repeating Aristotle claim adout the eidos, namely that the eidos of the living beings is the soul. ${ }^{56} \mathrm{In}$ other words if the eidos were to be destroyed then the soul would be destroyed too. In the Cononite florilegium ${ }^{57}$ there is a quotation from Philoponus saying the same thing about the resurrected bodies, namely: "but they will be not identical to them according to the eidos, because, in the resurrection, they will be incorruptible and immortal."

After a thorough study of this passage Lourié proposed a resolution of this contradiction by considering that in the Philoponean passage mentioned above there is a wrong "not" that if one were to omit would make it: the resurrected bodies must be different from the dead ones by number < that is, by

\footnotetext{
53 Lourié, "John Philoponus on the Bodily Resurrection," pp. 80-81, and Wickham, "John Philoponus and Gregory of Nyssa's Teaching on Resurrection," pp. 206-210.

$54 \quad P G$ 86,1, col. 62D-64A.

55 Philoponus, Commentary on the Categories, ed. A. Busse (CAG, 13,1), Berlin, 1898, p. 34.13-

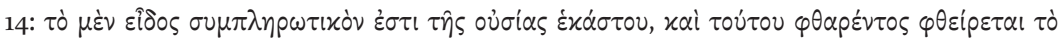
iं

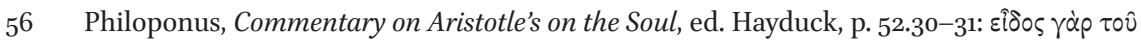

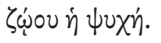

57 Van Roey, "Un traité cononite contre la doctrine de Jean Philopon sur la Résurrection," pp. $136-137$.
} 
physical identity>, but not by the eidos. And he verifies his hypotheses by comparing a parallel passage of the work Arbiter ${ }^{58}$ which is extant only in Syriac version, and which mentions exactly what Lourié is proposing.

Thus, Lourié concluded that Philoponus' teaching on the resurrected bodies is the following: the resurrected bodies are physically different from the corruptible bodies but share with them a common soul, which is for them their eidos that makes them rational beings, that is, humans. The identity between the resurrected person and the dead person is secured both by their common soul and by their common eidos, which, in the case of the resurrected persons is applied to a different matter consisting of different elements. Consequently the nature of the body before and after the resurrection is changed, but the nature of the whole human being is not affected. ${ }^{59}$

Of course the reconstruction of the teaching of Philoponus done by Lourié shows him having the same opinion that Origen held in the past. For as we saw, according to Origen too the eidos of the human beings does not change, it is their body that changes.

\section{Conclusion}

Concluding, we can make the following observations: The official Christian view concerning the resurrection of the dead was that it is the same flesh that rises again, although in a state of glory and eternal. The Christian writers who held this opinion did not approach their conception in a philosophic way; in other words they were not interested whether their argumentation was pertinent in a philosophic-logical way. The exceptions to this doctrine, Origen and Philoponus, seem to be both influenced by philosophical doctrines, and both of them professed a change according to matter, but not according to the eidos, so as to preserve a logical, philosophically speaking, identity of the previous human being with the risen one. They were most probably influenced by the neo-Platonic doctrine of the "subtle body of the soul" which they combined with the "spiritual body" mentioned by the Apostle Paul, and, at the same time, they adopted Aristotelian logic. Thus, in the teaching of both Origen and Philoponus we find a fusion of the philosophy of their time and of Christian doctrine.

$5^{8}$ Ioannes Philoponus, Opuscula monophysitica, ed. A. Šanda, Beirut, 1930, 10.37, p. 34.21-24.

59 Lourié, "John Philoponus on the Bodily Resurrection," p. 88. 